\title{
TEKNIK SAMPLING SNOWBALL DALAM PENELITIAN LAPANGAN
}

\author{
Nina Nurdiani \\ Architecture Department, Faculty of Engineering, BINUS University \\ Jln. K.H. Syahdan No. 9, Palmerah, Jakarta Barat 11480 \\ nnurdiani@binus.edu, nina.nurdiani@yahoo.co.id
}

\begin{abstract}
Field research can be associated with both qualitative and quantitative research methods, depending on the problems faced and the goals to be achieved. The success of data collection in the field research depends on the determination of the appropriate sampling technique, to obtain accurate data, and reliably. In studies that have problems related to specific issues, requiring a non-probability sampling techniques one of which is the snowball sampling technique. This technique is useful for finding, identifying, selecting and taking samples in a network or chain of relationships. Phased implementation procedures performed through interviews and questionnaires. Snowball sampling technique has strengths and weaknesses in its application. Field research housing sector become the case study to explain this sampling technique.
\end{abstract}

Keywords: field research, snowball sampling technique

\begin{abstract}
ABSTRAK
Penelitian lapangan dapat terkait dengan metode penelitian kualitatif maupun kuantitatif, tergantung pada permasalahan yang dihadapi dan tujuan yang ingin dicapai. Keberhasilan pengumpulan data di lapangan tergantung pada penentuan teknik sampling yang tepat, untuk mendapatkan data yang akurat, dan andal. Pada penelitian yang memiliki permasalahan terkait isu-isu yang spesifik, membutuhkan teknik sampling nonprobabilitas salah satunya adalah teknik sampling snowball. Teknik ini bermanfaat untuk menemukan, mengidentifikasi, memilih dan mengambil sampel dalam suatu jaringan atau rantai hubungan. Prosedur pelaksanaannya dilakukan bertahap melalui wawancara mendalam dan kuesioner. Teknik sampling snowball memiliki kekuatan dan kelemahan dalam penerapannya. Penelitian lapangan bidang perumahan menjadi kasus studi untuk membantu menjelaskan teknik sampling ini.
\end{abstract}

Kata kunci: penelitian lapangan, teknik sampling snowball 


\section{PENDAHULUAN}

Penelitian lapangan seringkali memiliki kompleksitas yang tinggi, melibatkan banyak aspek dan menuntut pendekatan antar disiplin ilmu, baik ekonomi, sosial-budaya, psikologi, politik, hukum, teknik, dan lingkungan. Penelitian juga dapat melibatkan berbagai pihak terkait, seperti pemerintah, swasta, masyarakat, kelompok masyarakat, atau individu. Penelitian lapangan dapat dilaksanakan dengan metode kualitatif maupun kuantitatif, tergantung pada permasalahan yang akan dijawab dan tujuan yang ingin dicapai. Pengumpulan data di lapangan dilakukan dengan menentukan terlebih dahulu teknik sampling yang akan digunakan untuk mendapatkan data yang akurat, andal dan dapat dipertanggungjawabkan.

Pada penelitian lapangan yang memiliki permasalahan khusus, metode penelitian kuantitatif dengan teknik sampling probabilitas seringkali tidak tepat untuk digunakan, misalnya untuk kasuskasus yang berkaitan dengan isu privacy pemilik rumah, kepemilikan penghunian, dan lain sebagainya. Sebagai alternatif dapat digunakan teknik sampling non-probabilitas salah satunya adalah teknik sampling snowball.

Artikel ini bermaksud untuk menjelaskan teknik sampling snowball sebagai salah satu teknik sampling yang dapat diandalkan untuk mendapatkan data dari responden guna menjawab permasalahan penelitian lapangan yang bersifat khusus. Studi kasus untuk menjelaskan teknik sampling snowball ini menggunakan penelitian lapangan bidang perumahan. Pembahasan dimulai dengan penjelasan mengenai tuntutan penelitian lapangan bidang perumahan, karakteristik teknik sampling snowball, relevansi penerapan teknik sampling snowball, kekuatan dan kelemahan teknik ini, diakhiri dengan kesimpulan.

\section{Tuntutan Penelitian Lapangan Bidang Perumahan}

Penelitian lapangan memiliki pendekatan yang lebih bersifat kualitatif, sangat mengandalkan pada data lapangan yang diperoleh melalui informan, responden, dokumentasi atau observasi pada setting sosial yang berkaitan dengan subyek yang diteliti (Widodo \& Mukhtar, 2000). Dalam pelaksanaannya, peneliti mengamati responden secara langsung dan berpartisipasi di dalam setting sosial, serta menyatu dengan budaya yang ada (Burgess, 1982). Teknik pengamatannya dapat dilakukan dengan percakapan, wawancara terstruktur (formal), wawancara tidak terstruktur (informal), survey dan pengumpulan dokumen-dokumen pribadi (tulisan, rekaman percakapan, fotofoto, dan lain-lain). Teknik-teknik ini dapat digunakan dalam kombinasi yang berbeda-beda tergantung pada permasalahan penelitiannya.

Pada penelitian lapangan, banyak interaksi sosial yang perlu dilakukan oleh peneliti dengan responden yang diamati, untuk dapat memahami realitas sosial secara lebih mendalam. Penelitian lapangan seringkali menyita banyak waktu, melibatkan emosi dan secara fisik dapat mengundang bahaya. Penelitian lapangan di bidang perumahan memiliki karakteristik yang sama dengan penelitian lapangan di bidang sosial, khususnya dalam mengungkapkan permasalahan dan menemukan jawabannya. Umumnya penelitian ini memiliki pertanyaan penelitian yang terkait dengan pembelajaran, pemahaman dan penggambaran berbagai fenomena yang terjadi di masyarakat (Neuman, 2003).

Pengambilan sampel (sampling) adalah metoda sistematis untuk pemilihan subjek yang akan diteliti. Berikut ini diuraikan beberapa istilah umum yang perlu dipahami di dalam sampling, antara lain: (1) Unit observasi (unit analisis), yaitu unit dasar yang dijadikan objek observasi dalam penelitian. (2) Populasi, yaitu himpunan unit observasi yang lengkap dan utuh, terdiri dari nilai atau ukuran peubah-peubah yang bersifat majemuk. (3) Sampel, yaitu himpunan unit observasi (bagian dari 
populasi) yang memberikan keterangan atau data untuk suatu penelitian, terdiri dari nilai atau ukuran peubah-peubah yang bersifat terbatas jumlahnya. Sampel diperlukan apabila ukuran populasi penelitian relatif besar. (4) Sampel representatif, yaitu himpunan unit observasi yang dianggap cukup mewakili karakteristik tertentu yang dimiliki populasi.

Tujuan pengambilan sampel (sampling) adalah untuk memperoleh gambaran deskriptif tentang karakteristik unit observasi yang termasuk di dalam sampel, dan untuk melakukan generalisasi serta memperkirakan parameter populasi. Hal ini dilakukan karena peneliti tidak dapat melakukan pengamatan secara langsung pada semua unit analisis atau individu yang berada dalam populasi penelitian. Peneliti mengambil data dari sebagian populasi yang disebut sampel untuk mewakili populasi. Dalam memilih metoda sampling yang akan digunakan, perlu dipertimbangkan anggaran biaya penelitian, batasan waktu penelitian, ketersediaan pengetahuan tentang populasi, informasi ukuran populasi, aksesibilitas terhadap unit observasi, tingkat generalisasi yang ingin dicapai, dan ketersediaan fasilitas pendukung. Penggunaan kombinasi beberapa metoda pengambilan sampel sangat umum digunakan dalam suatu penelitian guna mencapai tujuan penelitian dan memberikan hasil penelitian yang berkualitas, akurat, memenuhi kriteria, dapat dipercaya dan diandalkan.

Teknik sampling yang digunakan pada penelitian di bidang perumahan dapat beragam dan sangat terkait dengan permasalahan penelitian yang akan dijawab. Secara umum ada dua teknik sampling yang dapat digunakan, yaitu sampling probabilitas yang cenderung bersifat kuantitatif dengan analisis statistik, dan teknik sampling non-probabilitas yang cenderung bersifat kualitatif. Untuk menjawab permasalahan khusus yang sulit diungkapkan dan tidak mudah dianalisis secara statistik, maka teknik sampling non-probabilitas akan lebih tepat dan dapat lebih berguna dalam proses pengumpulan data. Teknik sampling non-probabilitas bertujuan untuk mengidentifikasi hal-hal yang masih belum jelas dalam penelitian pendahuluan, untuk mendapatkan gambaran tentang kumpulan unit observasi yang kemudian dijadikan landasan bagi penerapan sampel probabilitas yang lebih tepat dan akurat. Dalam teknik sampling non-probabilitas ada beberapa teknik sampling yang dapat digunakan, seperti dijelaskan dalam tabel 1 .

Menurut Becker (1970), dalam menyiapkan penelitian lapangan, setelah memutuskan lokasi dan waktu penelitian, peneliti harus menentukan responden yang akan diteliti. Dalam beberapa studi perumahan, kelompok-kelompok seperti penghuni perumahan real estat atau anak-anak yang tinggal di lingkungan perumahan flat, dapat didefinisikan dengan lebih jelas oleh peneliti. Namun, dalam kasus tertentu, kelompok atau orang sebagai responden tidak dapat ditentukan dengan jelas. Dalam kondisi seperti ini, para peneliti menemukan kesulitan mengenai siapa yang harus diteliti. Beberapa peneliti mengatasi situasi seperti ini dengan menggunakan teknik sampling snowball. Mereka memanfaatkan informan-informan kunci untuk mengantarkan peneliti pada anggota kelompok atau orang yang distudi.

Burgess (1982) juga menjelaskan bahwa informan-informan kunci pada penelitian lapangan tidak hanya menyediakan data yang detail dan rinci dari suatu setting khusus, tetapi juga membantu peneliti menemukan informan kunci lainnya atau membuka akses pada responden yang akan diteliti. Dengan demikian, pada situasi dan kondisi khusus di mana pertanyaan dan permasalahan penelitian di bidang perumahan terkait pada isu-isu yang spesifik, peneliti dapat menghadapi kesulitan dalam menemukan atau mengidentifikasi responden yang akan diteliti. Untuk dapat mengatasi masalah tersebut, maka teknik sampling snowball sebagai salah satu teknik sampling non-probabilitas, dapat digunakan untuk pengumpulan data guna menjawab permasalahan penelitian. Dengan menggunakan teknik ini diharapkan penelitian lebih mudah dilaksanakan dan diselesaikan. 
Tabel 1 Jenis-jenis Sampling dalam Teknik Sampling Non-Probabilitas

\begin{tabular}{|c|c|}
\hline Jenis Sampling & Prinsip Pelaksanaan \\
\hline $\begin{array}{l}\text { Haphazard } \\
\text { (sembarang, seadanya) }\end{array}$ & $\begin{array}{l}\text { Mengambil berbagai kasus dengan cara-cara yang disukai peneliti. Jenis } \\
\text { sampling ini sebaiknya dihindari. }\end{array}$ \\
\hline $\begin{array}{l}\text { Quota } \\
\text { (memilih / menentukan } \\
\text { kategori) }\end{array}$ & $\begin{array}{l}\text { Mengambil sejumlah kasus yang diawali dengan menentukan beberapa } \\
\text { kategori yang dapat menunjukkan perbedaan populasi, menggunakan } \\
\text { metode haphazard. }\end{array}$ \\
\hline $\begin{array}{l}\text { Purposive } \\
\text { (menentukan / menyesuaikan) }\end{array}$ & $\begin{array}{l}\text { Mengambil semua kasus yang mungkin sesuai dengan kriteria tertentu } \\
\text { melalui penggunaan berbagai metode. }\end{array}$ \\
\hline $\begin{array}{l}\text { Snowball } \\
\text { (bola salju) }\end{array}$ & $\begin{array}{l}\text { Mengambil sejumlah kasus melalui hubungan keterkaitan dari satu orang } \\
\text { dengan orang yang lain atau satu kasus dengan kasus lain, kemudian } \\
\text { mencari hubungan selanjutnya melalui proses yang sama, demikian } \\
\text { seterusnya. }\end{array}$ \\
\hline $\begin{array}{l}\text { Deviant Case } \\
\text { (kasus penyimpangan) }\end{array}$ & $\begin{array}{l}\text { Mengambil kasus-kasus yang secara substansi berbeda dari pola-pola yang } \\
\text { dominan (suatu tipe khusus dari sampling purposive). }\end{array}$ \\
\hline $\begin{array}{l}\text { Sequential } \\
\text { (berurutan) }\end{array}$ & $\begin{array}{l}\text { Mengambil kasus-kasus sampai tidak ada informasi tambahan atau } \\
\text { karakteristik - karakteristik yang baru (sering digunakan bersama metoda } \\
\text { sampling yang lain). }\end{array}$ \\
\hline $\begin{array}{l}\text { Theoretical } \\
\text { (bersifat teoritik) }\end{array}$ & $\begin{array}{l}\text { Mengambil kasus-kasus yang akan membantu memunculkan gambaran yang } \\
\text { penting secara teoritik mengenai suatu topik / setting tertentu. }\end{array}$ \\
\hline
\end{tabular}

Sumber: Neuman, 2003

\section{Karakteristik Teknik Sampling Snowball}

Teknik sampling snowball adalah suatu metode untuk mengidentifikasi, memilih dan mengambil sampel dalam suatu jaringan atau rantai hubungan yang menerus. Peneliti menyajikan suatu jaringan melalui gambar sociogram berupa gambar lingkaran-lingkaran yang dikaitkan atau dihubungkan dengan garis-garis. Setiap lingkaran mewakili satu responden atau kasus, dan garis-garis menunjukkan hubungan antar responden atau antar kasus (Neuman, 2003). Pendapat lain mengatakan bahwa teknik sampling snowball (bola salju) adalah metoda sampling di mana sampel diperoleh melalui proses bergulir dari satu responden ke responden yang lainnya, biasanya metoda ini digunakan untuk menjelaskan pola-pola sosial atau komunikasi (sosiometrik) suatu komunitas tertentu (gambar 1).

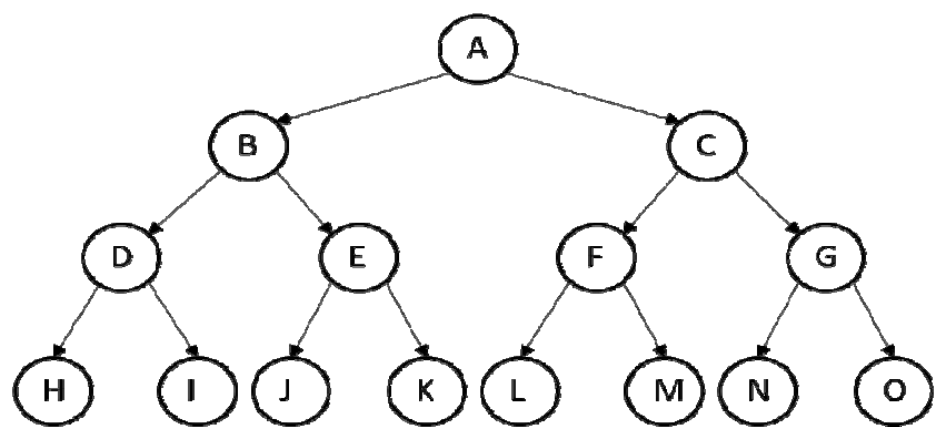

Gambar 1 Bagan Teknik Sampling Snowball 
Pada pelaksanaannya, teknik sampling snowball adalah suatu teknik yang multitahapan, didasarkan pada analogi bola salju, yang dimulai dengan bola salju yang kecil kemudian membesar secara bertahap karena ada penambahan salju ketika digulingkan dalam hamparan salju. Ini dimulai dengan beberapa orang atau kasus, kemudian meluas berdasarkan hubungan-hubungan terhadap responden. Responden sebagai sampel yang mewakili populasi, kadang tidak mudah didapatkan langsung di lapangan. Untuk dapat menemukan sampel yang sulit diakses, atau untuk memperoleh informasi dari responden mengenai permasalahan yang spesifik atau tidak jelas terlihat di dunia nyata, maka teknik sampling snowball merupakan salah satu cara yang dapat diandalkan dan sangat bermanfaat dalam menemukan responden yang dimaksud sebagai sasaran penelitian melalui keterkaitan hubungan dalam suatu jaringan, sehingga tercapai jumlah sampel yang dibutuhkan.

Dalam sampling snowball, identifikasi awal dimulai dari seseorang atau kasus yang masuk dalam kriteria penelitian. Kemudian berdasarkan hubungan keterkaitan langsung maupun tidak langsung dalam suatu jaringan, dapat ditemukan responden berikutnya atau unit sampel berikutnya. Demikian seterusnya proses sampling ini berjalan sampai didapatkan informasi yang cukup dan jumlah sampel yang memadai dan akurat untuk dapat dianalisis guna menarik kesimpulan penelitian (gambar 1). Contoh cara pelaksanaan teknik sampling snowball ditunjukkan pada penelitian terhadap tunawisma di Jakarta. Pada awalnya sulit sekali menemukan tunawisma hanya berdasarkan wilayah, namun setelah ditemukan satu atau lebih tunawisma di suatu area, maka dengan mudah dapat ditemukan tunawisma-tunawisma lain sebagai sampel melalui teknik sampling snowball.

Tabel 2 memberikan penjelasan ringkas mengenai teknik sampling snowball. Gambar 1 dan gambar 2 memperlihatkan bagan cara pengambilan sampel menggunakan teknik sampling snowball.

Tabel 2 Ringkasan Teknik Sampling Snowball

Teknik Sampling Snowball

\section{Deskripsi:}

Snowball sampling adalah suatu pendekatan untuk menemukan informan-informan kunci yang memiliki banyak informasi. Dengan menggunakan pendekatan ini, beberapa responden yang potensial dihubungi dan ditanya apakah mereka mengetahui orang yang lain dengan karakteristik seperti yang dimaksud untuk keperluan penelitian. Kontak awal akan membantu mendapatkan responden lainnya melalui rekomendasi. Untuk mencapai tujuan penelitian, maka teknik ini didukung juga dengan teknik wawancara dan survey lapangan.

\section{Manfaat:}

Efektif untuk penelitian yang terkait dengan komunitas yang terselubung, isu-isu yang sulit diungkapkan dengan jelas atau tidak terlihat nyata, isu-isu komunikasi, dan lain sebagainya.

Jumlah orang atau responden awal yang diperlukan:

- $\quad$ Medium (2-12 orang).

Ukuran sampel:

- $\quad$ Besar (>30).

- Medium (10 - 30).

Waktu yang diperlukan untuk pelaksanaan:

- $\quad$ Medium (6 minggu -6 bulan).

- $\quad$ Pendek ( $<6$ minggu). 


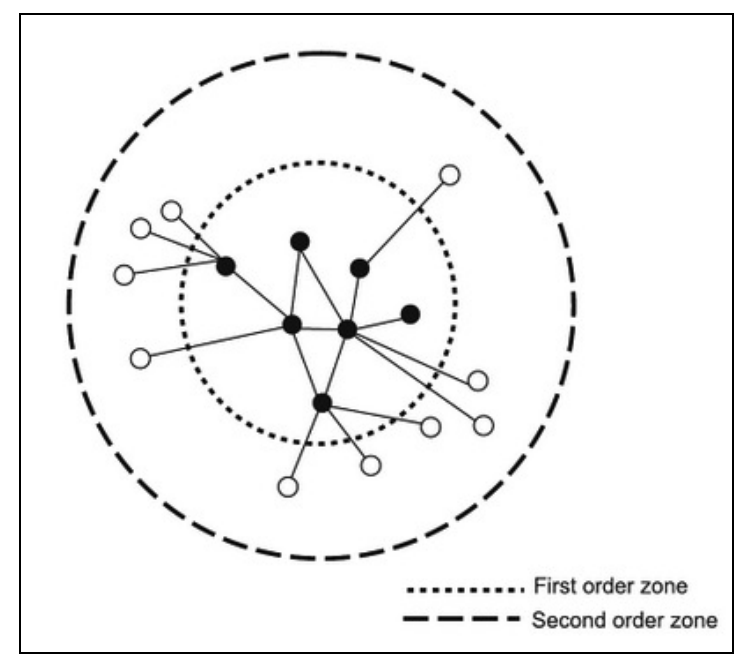

Gambar 2 Visualisasi Dua Area Sampling Menggunakan Teknik Sampling Snowball

Sumber: www. wikipedia.org

Prosedur pelaksanaan teknik sampling snowball dapat dilakukan bertahap dengan wawancara mendalam dan kuesioner. Dalam mewawancara responden, seorang interviewer harus memiliki kejujuran, kesabaran, rasa empati, dan semangat yang tinggi dengan tujuan untuk menghasilkan data yang dibutuhkan. Wawancara mendalam dilakukan dengan sejumlah daftar pertanyaan. Umumnya wawancara lapangan ini memiliki karakteristik awal dan akhir yang tidak terlihat jelas. Pertanyaan yang diajukan disesuaikan dengan kondisi dan situasi di lapangan. Wawancara lebih banyak bersifat informal dan fleksibel, mengikuti norma yang berlaku pada setting lokal, kadang diselipkan dengan canda-tawa yang dapat mencairkan suasana dan membina hubungan yang erat serta meningkatkan kepercayaan individu yang diteliti. Menurut Neuman (2003), konteks sosial dan setting wawancara perlu ditulis dalam catatan lapangan dan dilihat sebagai hal yang penting untuk mendukung penafsiran makna.

\section{Relevansi Penerapan Teknik Sampling Snowball}

Penerapan teknik sampling snowball pada penelitian lapangan di bidang perumahan, dapat memberikan kontribusi yang besar dalam mengungkapkan fenomena khusus di bidang perumahan. Salah satu penelitian perumahan yang diuraikan berikut ini, merupakan contoh penerapan teknik sampling snowball di bidang perumahan. Kerr (2008) menggunakan teknik sampling snowball dalam penelitiannya di bidang perumahan yang memfokuskan studi pada golongan menengah yang bermukim di kompleks perumahan Araya dan Sawojajar, Malang - Jawa Timur. Tujuan penelitian adalah untuk mengetahui mengapa anggota golongan menengah ingin bermukim di kompleks perumahan yang distudi, interaksi mereka dalam perumahan, dan gaya hidup anggota golongan menengah yang bermukim di perumahan.

Pada awalnya, peneliti diperkenalkan oleh dua dosen Universitas Muhammadiyah Malang kepada teman dan keluarganya yang tinggal di kedua perumahan tersebut. Setelah itu, teknik snowball sampling digunakan untuk mencari responden lain. Dengan kata lain, peneliti mendapatkan responden lain yang bersedia diwawancarai atas rekomendasi responden sebelumnya. Responden untuk penelitian ini berjumlah dua puluh orang. Sepuluh responden tinggal di perumahan Sawojajar, sedangkan sepuluh responden lainnya tinggal di perumahan Araya. 
Teknik pengumpulan data utama yang digunakan dalam penelitian ini adalah wawancara. Teknik wawancara digunakan karena dianggap paling bermanfaat untuk memperoleh informasi dari responden. Melalui wawancara, responden diberi kesempatan untuk menjelaskan pendapatnya, serta menceritakan pengalaman dan pengamatan mereka sendiri. Wawancara setengah-terstruktur digunakan dalam penelitian ini. Daftar pertanyaan digunakan sebagai pemandu wawancara. Apabila ada pendapat atau cerita menarik yang diungkapkan oleh responden, maka pertanyaan tambahan dapat langsung diajukan untuk memperoleh data lebih rinci. Untuk melengkapi informasi, observasi lapangan juga dilakukan di kedua perumahan tersebut.

Hasil penelitian memberikan gambaran bahwa kompleks perumahan menyediakan taraf hidup yang tinggi, dan lebih menarik golongan menengah untuk tinggal di sana. Golongan menengah ke atas menyebutkan faktor keamanan dan keselamatan sebagai alasan utama mereka pindah ke perumahan, sedangkan golongan menengah ke bawah cenderung memberi alasan karena lingkungan yang tenang. Tingkat individualisme golongan menengah ke atas biasanya lebih tinggi daripada golongan menengah ke bawah. Interaksi golongan menengah ke atas dengan warga perumahan lain cenderung terbatas. Budaya tetap penting untuk golongan menengah. Namun, golongan menengah ke bawah lebih aktif dalam mempertahankan budaya dan upacara tradisional. Pembangunan, kemajuan, pendidikan dan kerja keras merupakan nilai-nilai yang penting untuk golongan menengah. Golongan menengah memegang kuat agama dan percaya bahwa agama dapat menjadi pemandu moral dan penyaring untuk pengaruh buruk.

Contoh lain adalah penelitian perumahan yang dilakukan oleh Sukmajati (2008), yang mengungkapkan fenomena pelaku pembangunan perumahan skala kecil dan pemilik usaha rumah sewa (kontrakan), khususnya pemilik dan pembangun hunian sewa dua lantai atau lebih, yang dibangun dan dikelola secara swadaya oleh masyarakat. Tujuan penelitian ini adalah untuk mengungkapkan pembangunan yang dilakukan secara swadaya oleh masyarakat, yang dilihat sebagai "masalah" yang terkait standar kelayakan dan kesehatan bangunan, serta ketidakpedulian mereka terhadap regulasi perumahan yang berlaku. Penelitian dilakukan dengan pendekatan kualitatif menggunakan teknik sampling snowball untuk mendapatkan informasi dari informan kunci dan responden lainnya.

Untuk memperdalam isu pokok dan mengkaji interpretasi dalam kasus ini, digunakan wawancara mendalam dengan informan terpilih yang merupakan informan kunci baik perorangan maupun kelompok. Pemilihan informan perorangan ditentukan menurut status sosial anggota masyarakat yang dianggap memiliki peran dalam pembangunan perumahan swadaya masyarakat. Penelitian lapangan khususnya di bidang perumahan dengan teknik sampling snowball akan sangat bermanfaat untuk mengungkapkan realitas spesifik yang terkait dengan proses berhuni di lingkungan perumahan.

\section{Kekuatan Dan Kelemahan Teknik Sampling Snowball}

Teknik sampling snowball memiliki kekuatan, yaitu mampu menemukan responden yang tersembunyi atau sulit ditentukan, serta mampu mengungkapkan hal-hal yang spesifik atau yang tabu dalam dunia sosial. Meskipun demikian, teknik ini tetap memiliki kelemahan dalam pelaksanaannya. Tabel 3 dan tabel 4 memberikan penjelasan mengenai kekuatan dan kelemahan dari teknik sampling snowball. Penggunaan teknik sampling snowball membutuhkan kemandirian yang tinggi dalam berpikir dan bertindak di lapangan, membutuhkan kreativitas tinggi untuk dapat mengungkapkan suatu hal sesuai dengan yang diharapkan, membutuhkan kesabaran-sensitifitas-kemampuan sosial dan rasa empati yang tinggi dari peneliti, membutuhkan sikap bersahabat, dapat dipercaya dan hati-hati dalam meng-interview responden, agar mereka mau mengungkapkan informasi yang dibutuhkan penelitian. 
Tabel 3 Kekuatan Teknik Sampling Snowball

\section{Kekuatan:}

- $\quad$ Penelitian dapat dimulai dengan informasi yang terbatas dari responden awal, namun pada akhirnya informasi berkembang luas dan mendalam.

- $\quad$ Membantu menemukan pihak-pihak yang terlibat dalam penelitian namun sulit ditemukan atau tidak diketahui keberadaannya.

- $\quad$ Meningkatkan jumlah responden dalam prosesnya guna mencapai hasil yang akurat.

- Membangun gagasan berdasarkan sumber-sumber dari jaringan yang terbentuk.

Sumber: Becker (1970); Burgess (1982);

Neuman (2003); Salganik (2007); Suhardjo (2008)

Tabel 4 Kelemahan Teknik Sampling Snowball

\section{Kelemahan:}

- Waktu pelaksanaan menjadi lebih lama apabila peneliti sulit membangun jaringan.

- $\quad$ Biaya penelitian dan tenaga yang dikeluarkan dapat bertambah dari perkiraan semula, apabila belum menemukan responden yang dimaksud.

- Hasil kurang mewakili populasi, apabila peneliti kurang teliti / hati-hati dalam menentukan sampel awal untuk membangun jaringan.

- Ada masalah etika yang harus dipertimbangkan ketika mempublikasikan data, terkait dengan jaminan kerahasiaan identitas responden, khususnya apabila terkait hal-hal yang dapat mengancam keamanan diri responden.

Sumber: Becker (1970); Burgess (1982);

Neuman (2003); Salganik (2007); Suhardjo (2008)

\section{SIMPULAN}

Penerapan teknik sampling snowball pada penelitian lapangan di bidang perumahan, sangat bermanfaat dalam mengungkapkan fenomena khusus di bidang perumahan. Teknik sampling snowball merupakan salah satu cara yang dapat diandalkan dalam menemukan atau mengidentifikasi responden yang dimaksud sebagai sasaran penelitian, melalui keterkaitan hubungan dalam suatu jaringan.

Prosedur pelaksanaan teknik sampling snowball dilakukan bertahap dengan wawancara mendalam dan kuesioner. Pada penerapannya, teknik sampling snowball memiliki kelebihan dan kekurangan. Untuk mencapai tujuan penelitian dan memudahkan pelaksanaannya, maka perlu strategi yang efisien dan efektif agar penelitian tidak banyak menyita waktu, hemat biaya dan tenaga, namun tetap memenuhi kriteria penelitian, yaitu akurat, dapat dipercaya, dapat diandalkan dan representatif. 


\section{DAFTAR PUSTAKA}

Becker, H. S. (1970). Sociological Work. New York: Transaction Books.

Burgess, R. G. (1982). Field Research: a Sourcebook and Field Manual. London: Unwin Hyman.

Kerr, J. (2008). Di Belakang Pagar Perumahan: Kampung-kampung Golongan Menengah di Malang, Jawa Timur. Malang: ACICIS-FISIP Universitas Muhammadiyah Malang.

Neuman, W. L. (2003). Social Research Methods, Qualitative and Quantitative Approaches. Fifth Edition. Boston: Pearson Education.

Patton, M. (1990). Qualitative evaluation and research methods. California: Sage Publications.

Salganik, M. J., Douglas D. H. (2007). Sampling and Estimation in Hidden Populations Using Respondent - Driven Sampling. Journal Sociological Methodology, 34(1).

Suhardjo, B. (2008). Statistik. Diakses 20 September 2013 dari www.one.indoskripsi.com.

Sukmajati, D. (2008). Rumah Susun Swadaya Masyarakat sebagai Potensi Percepatan Penyediaan Perumahan di Jakarta. Proceeding Seminar Nasional Perumahan. Jakarta: Jurusan Arsitektur Universitas Bina Nusantara.

Widodo, E., Mukhtar (2000). Konstruksi ke Arah Penelitian Deskriptif. Yogyakarta: Avyrouz. 